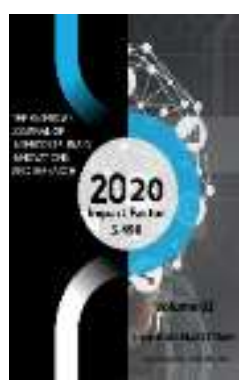

\title{
To The Question Of Interaction Of Theater And Cinema In The Art Culture Of Uzbekistan In The 1920s - 1930 S
}

\author{
Omina Bakhromovna Azizova \\ Phd Student, Academy Of Sciences Of The Republic Of Uzbekistan Institute Of Fine Arts, \\ Uzbekistan
}

Journal Website: http://usajournalshub.c om/index,php/tajiir

Copyright: Original content from this work may be used under the terms of the creative commons attributes 4.0 licence.

\section{ABSTRACT}

The article scientifically explores the ever-existing creative ties of Uzbek theater and cinema. Creative works created as a result of the repair of two independent arts were analyzed. The exchange of actors, the ever-evolving reflection, also transferred the culture of the performing arts to cinematography.

\section{KEYWORDS}

Theater, actor, cinema, director, genre, image, type, role.

\section{INTRODUCTION}

Uzbek theater and cinema have long been in close contact. The role of theater in the development of cinematography is invaluable. Theater and cinema have entered the second century in parallel creativity and have achieved a number of practical achievements in collaboration. As a result, a new problem for science - the interaction of theater and cinema, the need to study the relationship arose. Theorists used the terms "theater", "theatricality", "theatrical", "theatrical" in order to prove the independence of cinema. 
Attempts were in vain. Every decade of history has proved the influence of theater on cinema. The theater taught the selection of works in the first decade, the opening of the heroic character in the second decade, the creation of a stage environment in the third decade, the compositional order.

The relationship between theater and cinema has been strong in every time. The two independent arts have always worked in creative collaboration. This connection is especially striking in the field of acting. Uzbek acting has faced various obstacles, denials and prohibitions during its development. Stage and screen heroes created by strong-willed, professional theater actors were valued as a spiritual heritage. Over the years, theater actors have created new performing styles, directions, and schools by combining traditional, contemporary elements. National stage actors sought innovative findings, modern views, unique methods of interpretation in the formation and development of theater and cinema. The new Uzbek theater and cinematography were born, formed and developed in a strong creative partnership.

\section{METHODS}

Analytical methods such as description, classification, comparative analysis, scientific repair, and a holistic approach were used in the study of the interaction between theater and cinema. It is proposed to study the relationship between Uzbek theater and cinema, the phenomenon of interaction in five major periods. These are Phase 1 - 1920-1930, Phase 2 - 1940-1950, Phase 3-1960-1970, Phase 4 - 19801990, Phase 5 - years of independence. In this study, it was proposed to consider the process of synthesis of two independent arts in the 1920 s and 1930 s.

\section{RESULTS}

The study of the historical-theoretical aspects of the process of interaction of the national theater and cinema was determined in five stages. The first stage* is the beginning of creative contacts with theatrical art in the silent period of cinema. It was from this period that theatrical elements were reflected in the cinema, and elements of the performing arts came to life on the canvas.

In the 1920 s and 1930s, the skills of the first generation of talented actors in the theater increased and became more creative. The new Uzbek theater, formed on the basis of traditional amateur troupes, has influenced the overall development of national culture. Radical changes took place in the spiritual life of the people, and the training of national professionals began. In the mid-twenties, the demand for professional staff in the new Uzbek theater became more urgent. The Uzbek theater of the European type required balanced training in acting, directing and dramaturgy. Moscow and Baku studios are responsible for meeting the existing needs and training. The staff trained in the studios had to work in theater and cinema at the same time. He used the experience of theater actors on stage and the professional training he received in the development of cinema.

In November 1924, with the efforts of Mannon Uyghur, the Uzbek Drama Studio was established in Moscow. 24 talented actors of amateur theaters (troupes) with stage experience at the Uzbek Drama Studio under the House of Education in Moscow 
T.Saidazimova, S.Eshonto'raeva, Z.Hidoyatova, T.Sultonova, G.Isomov, H.Isomov, (from Tashkent), L.Nazrullaev, H.Latipov, S.Tabibullaev, Sh.Qayumov, (from Bukhara), B.Irmatov (from Kokand) studied the experience of mature theaters in practice and returned to improve their performance skills. The professional acting skills of the first swallows was a great achievement for the national theater, cinema. Studying in the studio under the guidance of coaches such as R.Simonov, M.Tolchanov, V.Kantsel, L.Sverdlin, O.Basov became an experimental field for theater actors. In the summer of 1926, a historic event took place in the cultural life of Uzbekistan. For the first time, the Uzbek audience was introduced to Gogol's comedy "Inspector" in their own language. The studio also reported on Moler's Greed. At this time, in 1926, N. Ganiev for the first time participated in the shooting of the silent film "Sun of Happiness" as an assistant director [7.11p.]. This participation was marked as the first step of Uzbek artists in the national cinema.

In 1925, another group of artists was sent to study at the MF Akhundov Theater College in Baku. The second group of S.Olimov, H.Nosirova, N.Alieva, H.Khojaev, Q.Khojaev, Z.Kobulov, R.Bobojonov, S.Juraboev left for Baku at the Baku Theater College. There is also information that "... dozens of artists (at the Theater College in Baku) studied in the workshop of Professor V.V.Sladkopevtsev and A.A.Turganov"[2.14p.]. The formation of the Uzbek State Sample Troupe in 1927 marked a new stage in the history of the national theater. At the heart of the troupe was an actor and director who had graduated from Moscow and Baku studios. Between 1927 and 1930, they staged performances of "Lion", "Halima",
"Farkhod and Shirin". "Moscow and Baku studios have played a key role in Uzbek professional acting education. But it was not the only way. The available materials on the history of the Uzbek theater contain a number of memoirs of the older generation of actors, based on which the regular professional training of actors and directors is described [5.10p.]. According to Mukhtarov, the actors were impressed by the performances of Russian theater actors who came to Uzbekistan on a tour, especially the performances of the Moscow Art Theater. It is also noted in the monograph of the scientist that the graduating studios also trained the actors in the regions when they returned to the Republic. In 1929, under the leadership of M.Uygur, the studio returned from Moscow and became the core of the team. Until now, the performances of that period serve as a model for all theater groups of the Republic in the art and stage culture [5.10p.], said I. Mukhtarov.

The Hamza Theater was established in Samarkand after the relocation of the theater troupe to the capital and the addition of graduates from Moscow and Baku studios to the team. The activities of the new creative team in the late 205 and 305 were controversial. D. Kadyrova said that the reason for the difficult situation was "V.V.Tikhonovich, who did not know the creative team and differed in his research and style, and then VS Witt was appointed artistic director. Tikhonovich, for example, explains that while staging K.Goldoni's comedy "A Look at Two Rich Men," he introduced a method of orientalization (Uzbekization) of his Western drama [6. 93p.]. 
In 1927-1930, the second studio students J.Koldoshev, B.Jamolov, A.Olimov, P.Rahimova, M.Khaydarov, A.Khasanov, M.Musaev, N.Alieva, R.Pirmuhammedov, A.Ismailov studied in Moscow. In the history of theater, the actors (studios) of this period were characterized as a very talented generation. At the same time, a great talent began to form in the theaters of the Republic. In the 1930s, there was a shortage of directors, and leading actors such as M. Mirakilov, Sh. Kayumov, R. Khamroev, A. Turdiev, A. Bakirov staged performances in various regional theaters. The directing and pedagogical activity of the actors accelerated the development of professional theater and led to an increase in acting skills. Theatrical actors of this period had a universal ability, and most of the performers sang songs, played various musical instruments, and were familiar with choreography. Musicality and bright plasticity added a special charm to their performance. In the thirties, theatrical actors performed practical work such as acting on stage, translating foreign dramatic works, writing plays, staging it, pedagogical (staff training), writing memoirs.

During this period, the first national feature films were made in Uzbekistan (Bukhara and Tashkent), and the artists mastered the new discoveries of the West, combining the rich performance, directing and dramatic heritage achieved on stage. In this way, cinematographers actively used the artistic traditions of theatrical art. But the silent era of national cinematography invited actors mainly from neighboring countries, and theater actors followed the creative process and mastered the technical requirements of the art of cinema.
"Death Tower" (1925) was the first feature film shot in Uzbekistan, which debuted not only in our country, but also in Central Asia. The film was co-produced by Sevzapkino (Leningrad) and Bukhkino [7.10p.]. The film was shot by theater actor,director VK Viskovsky. Although the work of art, which is a novelty for the Uzbek people, is not without its shortcomings, it has aroused the interest of the audience. The creative team of the film consisted entirely of foreign experts. In a series of screenings, theater actors were first invited to perform episodes to create a national character in the play, and then to interpret the main characters. In the 1920s and 1930s, national stage artists (actors, directors) who studied, researched and gained experience in the creation of feature films mastered the technical requirements of the new art. The creative team formed in Uzbekistan (Yu. Azamov, S. Iskandarov, M. Rahimov, R. Pirmuhammedov, A. Umarov) later worked as a major director and actor at Uzefilm. In the mid-twenties, the first Uzbek actors - S.Khojaev, K.Yormatov, R.Akhmedov, R.Pirmuhammedov - appeared in the film "Wolves of Ravot" [4. 3 p.], said M.Kopustin.

Created in the 1920s and 1930s, the film's protagonists have a strong ideological influence, appearing mainly as propagandists. "A cinematographer who lived and worked in 1928 recalls that on March 18, a mobile cinema arrived in the village. Due to the lack of a proper building, the session was held outdoors. Despite the severe cold, the crowd gathered in large numbers. After the speech, the picture "Wolves of Ravot" was shown. During the session, several women removed their veils. When the picture was over, the speaker came out and called on everyone to 
throw in the shawl. The rest of the blankets were thrown away: all the women returned home empty-handed"'[1. 16p.] The film shows the tragedy of a peasant family living in the village of Ravot. The work begins with the suppression of the pure feelings of the poor youth Jalil and Karomat. The oppressive rich Abu Nabi takes his daughter Karomat as his third wife in exchange for the debts of the poor farmer. In the film, R. Pirmuhammedov played the role of Kurboshi Akromkhan. The only female character in the play, Karomat, was performed by K. Pimenova. Between 1924 and 1929, most theater actors were involved in professional training. Educated in theater studios in Moscow and Baku, theater actors began creative collaborations with cinematography in the 1930s.

\section{DISCUSSION}

The interaction of the two arts, the creative collaboration, was strengthened by their development, progress. In 1930, such stage masters as R. Pirmuhammedov, A. Ismailov, M. Mirakilov starred in the films "The Last Beck", "Until Dawn", while national theater actors took part in the Theater Olympiad in Moscow (1930). "Two Uzbek teams will take part in the Olympics: the Hamza Theater (now the Uzbek National Academic Drama Theater) and the Uzbek State Musical Theater," she said. At the end of the Olympics, which lasted from June 15 to July 11, each participant will be given a separate opinion of the members of the prestigious jury. In particular, the Uzbek theater is advised not to "deviate from the successful form of national performance."[8. 2p.]

The creative collaboration of theater and cinema in the 1920 s and 1930 s were the first attempts, the first steps in interaction. Both arts were engaged in the training of professional staff, the formation of national creative teams. From 1924 to 1929, theater actors received professional training and were involved in stage and screen work. The first actors to enter the cinema from the theaters in 1920-1930: R. Pirmuhammedov ("Wolves of Ravot" 1927, "Chachvon" 1927, "Closed Wagon" 1928, "Under the Domes of the Mosque" 1928, "Leopard Woman" 1928, "The Last Beck" 1930 ,), M. Mirakilov ("Leprosy Woman" 1928, “Until Dawn” 1934), S. Khojaev ("Wolves of Ravot" 1927, "The Last Beck" 1930, "Until Dawn" 1934), O. Jalilov ("Death Well” "1934), N.Alieva (" Death Well "1934), A.Ismailov (“ Until Dawn"1934).

\section{CONCLUSSION}

American actress Kerry Hishon, who watched the actor's work on stage and screen, commented on the similarities and differences between the two independent arts. Kerry points out that the stage requires the actor to practice more, working on gestures, speech, voice, plastic behavior. The stage actor is required to be both physically and mentally fit. After all, a stage actor is required to be able to show the mental state of his protagonist to hundreds and thousands of spectators at a time, live, without any auxiliary means of expression. In cinema, the camera lens is a great help to the actor. The actor does not have to use excessive gestures to show the protagonist's pain. He can also express the hero's grief with a drop or two of tears. He is also not required to raise his voice on high curtains. After all, a microphone helps him. The actor's extravagant behavior in front of the 
camera is also not necessary. That, too, is a sham in screen art [3.3p.], says Kerry Hishon.

\section{REFERENCES}

1. Akbarov $\mathrm{H}$. It rained magic. Tashkent: G'. Literature and Art named after Ghulam, 1977. 16 pages.

2. Avdeeva L.A., Dyachenko V.A., Turdiev A. Theater named after Hamza. Tashkent: Goslitizdat, 1957.14 pages

3. Hishon K. Stage and Screen. A comparison of acting techniques// www.kerryhishon.com. 2019. 1 February

4. Kopustin M. The search for accomplishment and the joy of discovery // Komsomolets Uzbekistan. 02/28/1974, No. 42, 3 p.

5. Mukhtarov I. Theater and its actors. Tashkent: Fan. 1989, 10 pp.

6. Qodirova D. Scenography of Uzbek theater of the XX century: composition and development processes. 17.00.01Theatrical art. Thesis submitted for an academic degree. Tashkent, 2010. 93 pages

7. Teshabaev J., Abulkosimova Kh., Hayitmatova S., Mirzamuhammedova M. Annotated catalog of artistic cinema of Uzbekistan [1925-2008]. Toshkent: Sanat. 2009. 10, 11 p.p.

8. To'laxo'jaeva M. Commonality of theatrical cultures: east and west.//World literature. 2016, №6.

9. Omonov, Q., \& Karimov, N. (2020). Importance of Ancestoral Heritage. The American Journal of Social Science and Education Innovations, 2(09), 196202.
10. Boltabayevich, B. B., \& Shodievna, B. O. (2020). Individual Approach To The Formation of Artistic And Creative Talents Of Students In Art Schools. The American Journal of Social Science and Education Innovations, 2(08), 637-642. 